\title{
ESTADO, INSTITUIÇÕES E REGULAÇÃO DAS ATIVIDADES ERVATEIRAS NO BRASIL
}

\author{
ESTADO, INSTITUCIONES Y REGULACIÓN DE LAS ACTIVIDADES YERBATERAS \\ EN BRASIL
}
THE STATE, INSTITUTIONS AND THE REGULATION OF YERBA-MATE ACTIVITIES IN BRAZIL

\section{ÉTAT, INSTITUTIONS ET RÉGULATION DES ACTIVITÉS DE PRODUCTION DU MATÉ AU BRÉSIL}

\author{
巴西政府和社会机构对草茶业的调节
}

DOI: 10.5533/1984-2503-20146105

Alcides Goularti Filho'

\section{RESUMO}

O objetivo deste artigo é discutir a inserção lenta e paulatina do Estado no processo de regulação e disciplinamento das atividades ervateiras no Brasil. O foco está concentrado nas ações empreendidas por meio de leis e decretos e da criação de instituições destinadas ao ordenamento da colheita, beneficiamento e comercialização da erva-mate. A atuação do Estado e das instituições ampliava-se concomitantemente com a formação e consolidação do complexo ervateiro que abrangia os estados do Paraná, Santa Catarina, Mato Grosso e Rio Grande do Sul. O texto está divido em cinco tópicos. Inicialmente será apresentado um panorama geral do complexo ervateiro, destacando o processo produtivo e as unidades que faziam parte desse complexo. Num segundo ponto, serão destacadas as primeiras leis aprovadas junto às províncias e pelo governo imperial durante o século XIX. Em seguida, serão analisados os mecanismos regulatórios aprovados entre 1900 e 1938 e a atuação dos institutos regionais do mate. E, no quarto tópico, serão apresentadas algumas iniciativas realizadas pelo Instituto Nacional do Mate durante a sua existência, entre 1938 e 1966. Por fim, o texto traz breves considerações finais.

Palavras-chave: Erva mate, Estado, legislação, instituições.

\footnotetext{
${ }^{1}$ Professor da Universidade do Extremo Sul Catarinense (UNESC). Doutor em Economia pela Universidade de Campinas (UNICAMP). Pesquisador Produtividade- Conselho Nacional de Desenvolvimento Científico e Tecnológico do Brasil (CNPq). Pesquisa financiada pelo Ministério da Ciência e Tecnologia e Inovação (MCTI)/CNPq. E-mail: alcides@unesc.net
} 


\section{RESUMEN}

El objetivo de este artículo es discutir la inserción gradual del Estado en el proceso de regulación y disciplina de las actividades yerbateras en Brasil. El foco está concentrado en las acciones emprendidas a través de las leyes y decretos y de la creación de instituciones destinadas al ordenamiento de la cosecha, beneficiación y comercialización de la yerba mate. La actuación del Estado y de las instituciones se ampliaba al mismo tiempo que la formación y consolidación del complejo yerbatero que abarcaba los estados de Paraná, Santa Catarina, Mato Grosso y Rio Grande do Sul. El texto está dividido en cinco tópicos. Inicialmente se presentará un panorama general del complejo yerbatero, destacando el proceso productivo y las unidades que formaban parte de este complejo. En otro momento, serán destacadas las primeras leyes aprobadas junto a las provincias y por el gobierno imperial durante el siglo XIX. Enseguida, se analizarán los mecanismos regulatorios aprobados entre 1900 y 1938 y la actuación de los institutos regionales del mate. En el cuarto tópico, se presentarán algunas iniciativas realizadas por el Instituto Nacional del Mate durante su existencia, entre 1938 y 1966. Por fin, el texto trae breves consideraciones finales.

Palabras-clave: Yerba mate, Estado, legislación, instituciones.

\section{ABSTRACT}

The aim of this article is to discuss the gradual insertion of the state in the process of regulating and supervising yerba-mate activities in Brazil. The focus is concentrated on actions undertaken by means of laws and decrees and in the creation of institutions dedicated to monitoring the cultivation, use and commercialization of yerba mate. The state's activities and those of the institutions expanded at the same time as the formation and consolidation of the yerba-mate complex covering the states of Paraná, Santa Catarina, Mato Grosso and Rio Grande do Sul. The text is divided into five sections. First, it presents a general panorama of the yerba-mate complex, highlighting the production process and the units which are part of this complex. It then goes on to highlight the first laws to be approved by the provinces and the imperial government in the nineteenth century. Next, it analyses the regulatory mechanisms approved between 1900 and 1938, and actions taken by the regional yerba-mate institutes. The penultimate section discusses 
several initiatives undertaken by the National Mate Institute, during its existence from 1938 to 1966 . Finally, the article presents its conclusions.

Key words: Yerba mate, the State, legislation, institutions.

\section{RÉSUMÉ}

L'objectif de cet article est d'analyser la lente et progressive insertion de l'État dans le processus de régulation et d'organisation des activités de production du maté au Brésil. Nous nous attacherons particulièrement aux actions entreprises au moyen de lois et décrets, ainsi qu'à la création d'institutions destinées à l'organisation de la récolte, de la transformation et de la commercialisation du maté. Le rôle de l'État et des institutions s'est amplifié de concert avec la formation et la consolidation d'un complexe agroindustriel de production du maté dans les États brésiliens du Paraná, Santa Catarina, Mato Grosso et Rio Grande do Sul. Le texte est divisé en cinq points. Nous commencerons par présenter un panorama général de la chaîne productive du maté, où nous mettrons l'accent sur les processus et les unités de production. En second lieu, nous aborderons les premières lois votées dans les provinces et par le gouvernement impérial au XIXème siècle. Seront ensuite analysés les mécanismes de régulation approuvés entre 1900 et 1938 et le rôle joué par les instituts régionaux du maté. Le quatrième point présentera les initiatives prises par l'Institut national du maté, en place entre 1938 et 1966 . Nous ferons enfin quelques brèves considérations à titre de conclusion.

Mots-clés : Maté, État, législation, institutions.

\section{摘要}

本论文旨在研究巴西政府缓慢逐渐介入巴西草茶生产加工销售等环节的监管和调节。重点研 究了巴西政府颁布的法令,并成立了巴西马特茶研究所。巴西政府的干预主要体现在巩固并 加强了多个产茶区, 巴那那,

圣特卡特琳娜, 马托各罗索, 南大河州。论文分为5部分。首先, 呈现给读者巴西草茶 (主要是马 特茶）的生产概况和几个知名生产者。其次,

介绍19世纪巴西帝国时代颁布的几个法令。第三, 分析在1900到1938年期间成立的监督机构和各个 茶区马特茶研究所的运作情况。第四, 研究巴西国家马特茶研究所在1938年到1966年期间的主要贡 献。最后,作者对议题做了总结。

关键词: 马特茶, 政府, 立法, 调节机构 


\section{Complexo regional ervateiro}

A erva-mate, classificada por Auguste Saint-Hilaire como Ilex paraguariensis, é um vegetal que convive com a floresta araucária no Brasil meridional. Com mais intensidade, havia no noroeste do Rio Grande do Sul, no planalto de Santa Catarina, no segundo e no terceiro planaltos do Paraná e no sul de Mato Grosso.

O uso da erva-mate como bebida, em infusão, era conhecido dos índios guaranis na América do Sul, ainda no período pré-colombiano. O hábito foi incorporado pelos espanhóis após a conquista dos territórios guaranis, cuja comunidade indígena foi sendo expulsa e acossada, até ser abrigada pelos jesuítas nos Sete Povos das Missões. Entre os jesuítas, o uso da erva-mate também foi disseminado, inclusive com o plantio de forma racional. O seu comércio era uma das mais importantes atividades econômicas do Paraguai durante os séculos XVIII e XIX. Na Argentina, o cultivo do vegetal ocorria apenas no nordeste do país, nas províncias de Misiones e Entre Rios. Contudo, quase toda a produção, que era baixa, destinava-se ao mercado interno ${ }^{2}$.

Entre os portugueses no Brasil, os primeiros contatos foram feitos pelos bandeirantes que seguiam para o sul da Colônia. Dos Sete Povos, o uso da erva-mate espraiou-se pelos pampas, chegando à região serrana e ao litoral do Continente de São Pedro do Rio Grande do Sul. O uso do mate como bebida, hábito diário dos gaúchos, foi ampliando o seu mercado com a presença de gaúchos e descendentes em outras regiões brasileiras. Suas propriedades químicas, nutritivas e curativas vão desde constatações plausíveis a lendas e mitos de ancestrais, como diurético, digestivo, evita a fadiga, retarda a fome e até rejuvenescedor e antidepressivo. De gosto amargo, utilizado com infusão a quente, mais conhecido como chimarrão, era, e continua sendo, a mais tradicional forma de consumo do mate no Brasil ${ }^{34}$.

Com relação ao processo produtivo da erva-mate, que envolve desde a colheita até a embalagem e a comercialização, durante o século XIX e o início do XX, ocorreram poucas mudanças tecnológicas, e podemos classificá-lo da seguinte forma:

- Colheita ou poda: a poda é realizada entre os meses de maio e agosto e compreende o desgalhamento do vegetal. São cortados os galhos e as folhas, deixando apenas o suficiente para a árvore viver e reproduzir. É realizada junto com a plantação, podendo

\footnotetext{
${ }^{2}$ Alencar, F. Rodrigues (1960). Erva-mate, Rio de Janeiro: Serviço de Informação Agrícola.

${ }^{3}$ Silva, Victor Ferreira do Amaral e Silva (1900). Erva-mate: sua cultura, colheita e preparo, Rio de Janeiro: Sociedade Nacional de Agricultura.

${ }^{4}$ Linhares, Temístocles (1969). História econômica do mate, Rio de Janeiro: Livraria José Olympio.
} 
ser na mata ou onde a erva foi cultivada. Essa atividade era feita por trabalhadores, portando apenas um facão.

- Sapecamento: consiste em passar, por alguns segundos, sobre as chamas de fogo os galhos verdes da erva-mate, recentemente cortados. As folhas murcham e estalam em função das chamas, podendo o processo ser manual ou em cilindros. Essa operação era realizada ainda na mata ou próximo à plantação da erva-mate.

- Quebra ou dessecação: após sapecada, a erva é enfeixada, separados os galhos mais finos dos mais grossos, para, em seguida, proceder-se à secagem.

- Secagem: após sapecada e quebrada, a erva segue para um dos procedimentos mais importantes, a secagem, que consiste em retirar toda a umidade do vegetal. Era feita no sistema barbaquá, em que a erva era depositada num cilindro que se comunicava com um sistema de aquecimento, evaporando a umidade das folhas e dos galhos.

- Canchear: seguida da secagem, a erva-mate é cancheada ou triturada. É um processo desenvolvido com o uso da força humana, em que a erva é colocada sobre uma armação de madeira e picada por facões, recebendo tratamento final nos pilões manuais. A erva-mate resultante é peneirada, sendo chamada de cancheada, cuja matéria-prima é utilizada nos engenhos de beneficiamento.

- Moagem: a erva sapecada e cancheada no engenho recebe o beneficiamento final por meio do sistema de soque, que é a moagem. Aí se dá a separação dos diversos tipos de erva, de acordo com a classificação comercial: grossa, fina e extrafina.

- Embalagem: a erva era acondicionada em, basicamente, quatro tipos de embalagens: sacos de algodão, barricas de pinho, pacotes de papel e latões ${ }^{5}$.

Todo esse processo, associado às atividades diretas e indiretas da produção, do beneficiamento, do transporte e da comercialização da erva-mate, formava o complexo regional ervateiro. Com base no estudo de Cano $^{6}$ sobre o complexo cafeeiro, podemos definir os seguintes elementos que compõem um complexo agrário mercantil regional:

a) Atividades produtoras da erva-mate,

b) Agricultura de alimentos e as atividades fabris produtoras de insumos para as unidades e a população, vinculadas ao complexo ervateiro,

\footnotetext{
${ }^{5}$ Costa, Francisco Leite Alves (1935). O mate: exploração, indústria e exportação, Rio de Janeiro: Diretoria de Estatística da Produção.

${ }^{6}$ Cano, Wilson (1990). Raízes da concentração industrial em São Paulo, São Paulo: Hucitec.
} 
c) Implantação de um sistema de transportes integrando as unidades produtoras aos portos,

d) Movimento imigratório e migratório,

e) Criação e expansão de atividades bancárias e comerciais (exportação e importação),

f) Desenvolvimento de infraestruturas, como armazéns, portos, energia e comunicações,

g) Ação estatal (federal e estadual), atuando nos gastos públicos e em mecanismos regulatórios.

Esses elementos interagem num fluxo constante, produzindo, beneficiando, comercializando e transportando a erva-mate, gerando efeitos de expansão da renda e diversificação dos investimentos, reduzindo os custos e aumentando a produtividade. Esses efeitos geravam economias de escala, expandindo o mercado e proporcionando maior especialização regional, diversificação econômica e integração comercial e produtiva dentro do próprio complexo ervateiro.

A expansão e consolidação das atividades ervateiras no Paraná e Santa Catarina, e, em menor proporção, no Mato Grosso e Rio Grande do Sul, formavam um grande complexo agroexportador regional inserido no padrão de acumulação da economia brasileira, que era pautada na economia agrária mercantil exportadora. Na sua trajetória de crescimento, o complexo ervateiro foi envolvendo cada vez mais novas atividades fabris, comerciais e transportes para dar o suporte necessário a sua acumulação. Também se destacava a atuação do Estado e de algumas instituições que davam o suporte legal e o amparo político para regular e normatizar as atividades produtivas e comerciais do complexo ervateiro. É justamente sobre a atuação do Estado, das instituições e dos mecanismos regulatórios voltados para as atividades ervateiras que trata este artigo.

\section{Regulação das atividades ervateiras no século XIX}

Com o início das atividades ervateiras nas províncias do sul do Império, por meio da colheita, beneficiamento e comercialização do mate, o Estado brasileiro começou a editar uma série de legislações que tinha como objetivo disciplinar e racionalizar essas atividades. A quantidade de medidas regulatórias crescia paulatinamente com a expansão 
do complexo ervateiro. O aumento da produção exigia das autoridades do Estado a publicação de normas disciplinares para delimitar a ação tanto de pequenos capitalistas como de grandes companhias ervateiras. Essa intervenção pública se acentuou com mais intensidade a partir do último quartel do século XIX e se dava em duas instâncias: as legislações provinciais e imperiais, e, após 1889, estaduais e federais.

Uma das primeiras publicações editadas pelo Império destinadas aos produtores da erva-mate foi em 1837, sob a coordenação da Repartição dos Negócios do Império. Era uma "Memória sobre a cultura e o fabrico da erva-mate" que continha informações sobre os métodos praticados nessa lavoura, cujas recomendações não diferenciavam muito das já realizadas pelos produtores. No entanto, essa "Memória" não normatizava os métodos de colheita, beneficiamento e comercialização, deixando os produtores e comerciantes livres para negociar, o que muitas vezes prejudicava a qualidade dos produtos exportados e pouco contribuía para a arrecadação fiscal ${ }^{7}$.

Como é de conhecimento, a emancipação do Paraná da província de São Paulo ocorreu em 19 de dezembro de 1853, e, no bojo das disputas, estavam em jogo os interesses econômicos relacionados às atividades ervateiras que a cada ano apresentavam volumes crescentes nas exportações. No primeiro relatório expedido pelo recém- implantado governo provincial do Paraná de 15 de julho de 1854, o presidente Zacarias de Góes e Vasconcellos denunciava as fraudes ocorridas no preparo e na comercialização da erva-mate:

A fraude em má hora, inspirada pela maldita sede de ganho, vem piorar notavelmente a condição do mate do País, porque os indivíduos, que dão às folhas da congonha a primeira preparação, costumam adicionar-Ihes folhas estranhas ${ }^{8}$.

Como medida preventiva para evitar tais fraudes, o governo da província do Paraná designou inspetores para fiscalizar o processo de beneficiamento da erva junto aos estabelecimentos localizados nos bairros de Curitiba. Para aqueles que agiam

\footnotetext{
${ }^{7}$ Brasil (1837). Relatório da Repartição dos Negócios do Império apresentado pelo Ministro Antonio Paulino Limpo de Abreu à Assembleia Geral Legislativa em 1837, Rio de Janeiro: Tipografia Nacional. Disponível em < http://www.crl.edu/brazil/ministerial/imperio> Acesso em junho de 2011.

8 Paraná (1854). Relatório do Presidente da Província Zacarias de Góes e Vasconcellos enviado à Assembleia Legislativa em 1854, Curitiba: Tipografia Paranaense de Cândido Martins Lopes, p. 69. Disponível em <http://www.crl.edu/brazil/provincial/parana> Acesso em junho de 2011.
} 
corretamente, ou seja, não adicionavam outros vegetais na mistura com o mate, era expedido um certificado que garantia que o produtor estava cumprindo seus deveres ${ }^{9}$.

Essa medida ganhou força de lei com a promulgação do Regulamento da ErvaMate, a Lei 19, de 18 de setembro de 1855. Seguramente, foi a primeira medida legislativa mais ampla aprovada no País que regulamentava a colheita, o beneficiamento e a comercialização do mate. Composta de apenas oito artigos, previa que o corte do mate poderia ser realizado entre os meses de fevereiro e agosto. No processo produtivo, o beneficiamento obrigatoriamente deveria ser realizado em carijó coberto, para evitar a umidade e a mistura com a terra, que deveria ser levada ao fogo no mesmo dia em que fosse sapecada, para em seguida ser malhada. Também estava proibida a compra de "erva visivelmente viciada". Aos que infringissem essas regras seria aplicada uma multa de $50 \$ 000$ a $100 \$ 000$. Para aqueles que faziam encomenda de erva de "mate misturado com erva de natureza estranha”, a multa seria duplicada. Além dos inspetores, qualquer cidadão poderia denunciar as infrações às autoridades policiais ${ }^{10}$.

O problema da falsificação do mate também deixava o Ministério da Agricultura, Comércio e Obras Públicas preocupado, pois ao mesmo tempo que defendia a ampliação das exportações, mostrava-se temeroso com a qualidade do vegetal extraído. Segundo o Ministro Jesuino Marcondes de Oliveira e Sá, deveriam ser tomadas "providências enérgicas em ordem a por paradeiro ao bárbaro processo de extração da erva"11. 0 Ministério propunha auxiliar com recursos financeiros a substituição do sistema arcaico de preparo do mate por outro mais "racional".

Mesmo com a regulamentação das atividades ervateiras, novamente o governo provincial do Paraná teve de adotar novas medidas para evitar e punir aqueles que falsificavam a erva-mate, misturando-a com outros vegetais. No Relatório de 1879, temos outra denúncia que expressava a indignação do governo:

Repetidas são as reclamações que tenho recebido a cerca da falsificação da ervamate, única indústria e principal produção da província, e que tanto concorre para o aumento de suas rendas. Não é de hoje que os industriais, toda vez que a ervamate aos mercados consumidores atinge um preço elevado, com ambição dos

\footnotetext{
${ }^{9}$ Ibidem.

10 Paraná (1855). Relatório do Presidente da Província Zacarias de Góes e Vasconcellos enviado à Assembleia Legislativa em 1855, Curitiba. Disponível em <http://www.crl.edu/brazil/provincial/parana> Acesso em junho de 2011.

${ }_{11}$ Paraná (1865). Relatório do Ministério da Agricultura, Comércio e Obras Públicas apresentado pelo Ministro Jesuino Marcondes de Oliveira Sá à Assembleia Geral Legislativa em 1865, Rio de Janeiro: Tipografia Universal Laemmert, p. 20. Disponível em <ttp://www.crl.edu/brazil/ministerial/imperio > Acesso em junho de 2011.
} 
lucros, tentam e conseguem desacreditar este importante ramo de comércio, causando não só grandes prejuízos à província, como aos particulares ${ }^{12}$.

Novamente, com o intuito de novamente normatizar as atividades ervateiras, 0 governo do Paraná aprovou a Lei 429, de 24 de abril de 1875, que alterou a época de colheita para 15 de fevereiro a 30 de setembro e determinou que poderia ser feita apenas uma poda a cada três anos na mesma árvore. Também estava prevista nesta lei a criação de novos impostos para produção e comercialização do mate ${ }^{13}$. No ano seguinte, em 20 de abril, foi promulgado o Regulamento do Fabrico do Mate, que detalhou o processo de beneficiamento do mate desde a sua colheita, sapeca, encarijamento, torrefação e o acondicionamento. As regras definidas neste regulamento, em boa medida, ficaram em vigor até os anos de $1930^{14}$. Até a virada do século, as leis provinciais destinadas à ervamate estavam relacionadas definição de alíquotas de exportação e importação, com destaque à Lei 810 , de 3 de novembro de 1885 , que criou um imposto de $2 \$ 000$ por 15 quilos de erva cancheada, em rama ou bruta.

No Rio Grande do Sul, o governo imperial autorizou, por meio do Decreto 5.478, de 26 de novembro de 1873, o funcionamento da Companhia Centro da Exportação da ErvaMate. De acordo com o decreto, os objetivos da companhia eram os seguintes: comprar, beneficiar, vender e exportar erva-mate do Rio Grande do Sul; negociar por compra e venda e exportação em todos os mais produtos da província; quando necessário poderá importar quaisquer gêneros nacionais ou estrangeiros.

Em Santa Catarina, por meio da Lei 743, de 23 de maio de 1874, que orçou as receitas e fixou as despesas, no seu Art. 40 isentou as exportações das seguintes mercadorias: flores artificiais e seus artefatos, chá, trigo, anil, algodão e erva-mate ${ }^{15}$. A exemplo do Paraná, até o final do século, seguiram leis que regulamentavam as tarifas comerciais da erva-mate catarinense, como a Lei 1.156, de 5 de novembro de 1887, que taxou em 2,0\% a exportação de erva fina e definiu que a cada 15 quilos de erva bruta e

\footnotetext{
12 Paraná (1879). Relatório do Presidente da Província Manuel Pinto de Souza Dantas Filho enviado à Assembleia Legislativa em 1879, Curitiba: Tipografia Perseverança, p. XII-XIII. Disponível em <http://www.crl.edu/brazil/provincial/parana> Acesso em junho de 2011.

${ }^{13}$ Ibidem.

${ }^{14}$ Martins, Romário (1926). Ilex-mate, chá sul americano, Curitiba: David Carneiro.

${ }^{15}$ Santa Catarina (1874). Coleção das Leis da Província de Santa Catarina de 1874, Desterro: Tipografia J. J. Lopes.
} 
rama seriam cobrados $1 \$ 000$, para a grossa, 500 réis, e para erva exportada em folha, 200 réis $^{16}$.

Em âmbito nacional, as medidas regulatórias começaram a partir de 1882 com aprovação de concessões de terrenos devolutos para a prática da colheita do vegetal. $\mathrm{O}$ primeiro a ser promulgado foi o Decreto 8.799, de 9 de dezembro de 1882, que concedeu a Thomaz Laranjeira a permissão por dez anos para colher junto aos ervais existentes nos limites do Mato Grosso, na fronteira com o Paraguai. Foi nessa área que se instalou a Companhia Mate Laranjeira, uma empresa que praticamente monopolizou as atividades ervateiras no Mato Grosso ${ }^{17}$. Outra concessão foi realizada em 1890, por meio do Decreto 520, de 23 de junho, a Thomaz Laranjeira, ampliando a área de abrangência em direção ao sul da província.

Nos anos seguintes, foram realizadas novas concessões, como a destinada a José de Azevedo Silva e Tertuliano Ramos, do Paraná (Decreto 769, de 20 de setembro de 1890), e a Ernesto Canac, Abdon Baptista e Procópio Gomes de Oliveira, de Santa Catarina (Decreto 1.273, de 10 de janeiro de 1891). Para evitar a especulação dos terrenos concedidos, o Decreto 376, de 5 de maio de 1890, declarou intransferíveis as concessões feitas para colheita do mate, seja por título de compra, venda ou permuta.

Com o intuito de contemporizar a disputa entre os Estados exportadores que definiam alíquotas diferenciadas, o Decreto Federal 724, de 6 de setembro de 1890, extinguiu todos os impostos de exportação da erva-mate independente da origem ou do destino. Entre os dois maiores Estados produtores havia uma disputa tributária em que Santa Catarina cobrava $1 \$ 000$ a cada 15 quilos de erva bruta exportados e o Paraná, $2 \$ 000$. Além disso, havia diferenças nas tarifas portuárias, na qualidade e no tipo da erva comercializada. Por exemplo, a reclamação de alteração na composição do mate com a mistura de outros vegetais era mais comum no Paraná e Mato Grosso. Mesmo com a entrada em vigor deste decreto federal, os Estados produtores continuaram taxando suas exportações, pois era a maior fonte de arrecadação para o tesouro estadual.

Para disciplinar mais a concessão de terras no Mato Grosso, a Assembleia Legislativa do Estado aprovou a Lei 26, de 11 de novembro de 1892, cuja área compreendida entre os rios Iguatemi e Paraguai e as linhas de fronteira com a República

\footnotetext{
${ }^{16}$ Santa Catarina (1887). Leis e resoluções da Província de Santa Catarina de 1887, Desterro: Tipografia do Conservador.

17 Brasil (1882). Coleção de Leis do Império do Brasil de 1882, Rio de Janeiro: Imprensa Nacional. Disponível em < http://www.camara.gov.br/Internet/InfDoc/Conteudo/Colecoes/Legislacao > Acesso em junho de 2011.
} 
do Paraguai até a cabeceira do rio Iguatemi só poderia ser utilizada para a extração da erva-mate mediante concorrência pública, com prazo máximo de ocupação de dez anos ${ }^{18}$. No gráfico abaixo, podemos acompanhar a trajetória da evolução das exportações da erva-mate no Brasil entre 1850 e 1900. Foi justamente nesse período que se implantou o moderno sistema de transporte e proliferaram os engenhos e as casas comerciais. O que mais chama a atenção é sua trajetória ascendente, com uma leve desaceleração entre 1875 e 1885.

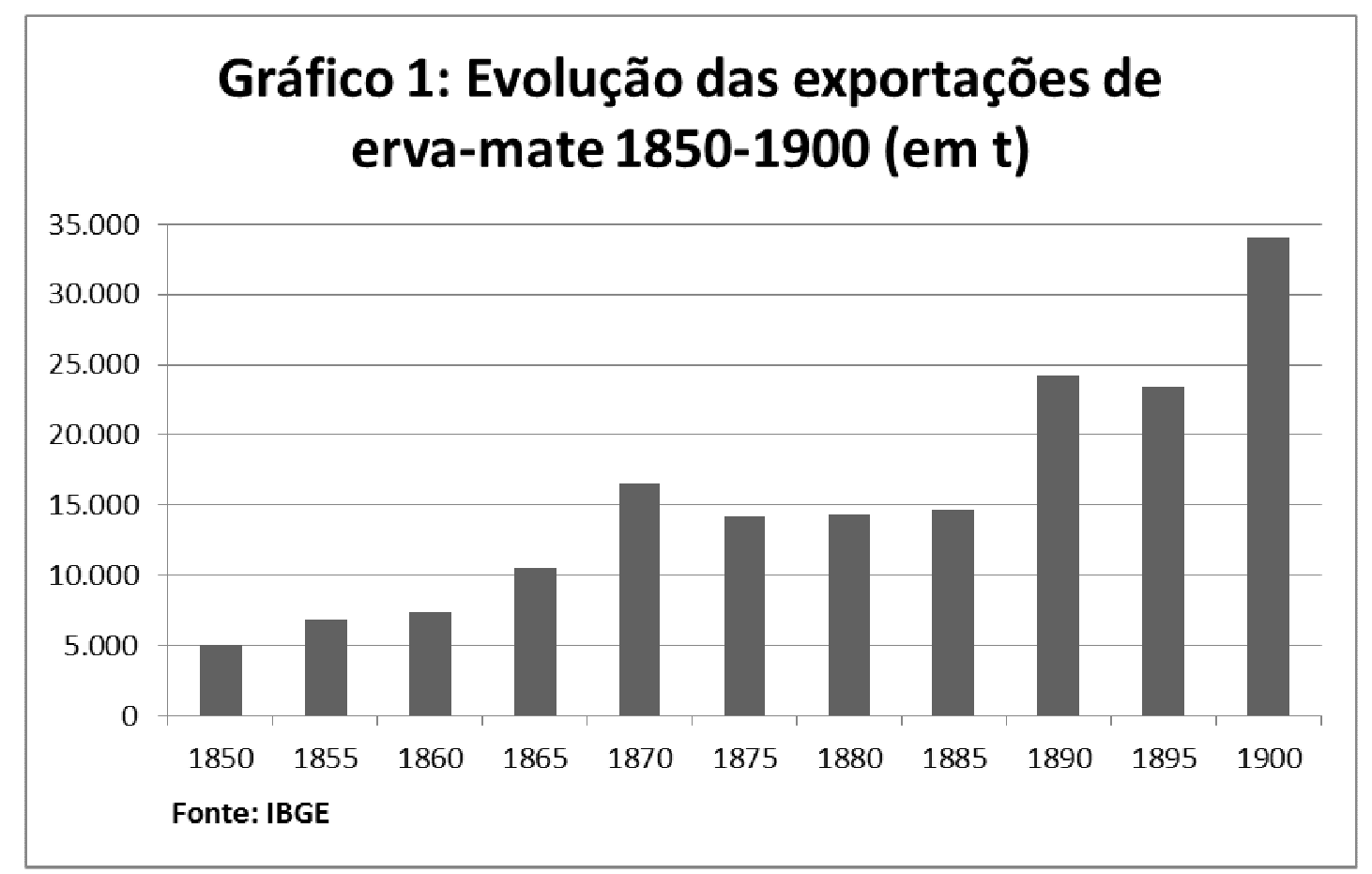

A primeira entidade criada no País para defender os interesses dos produtores e comerciantes foi a Associação Paranaense de Propaganda da Erva-Mate, instituída pela Lei 888 , de 23 de março de 1888, cujo objetivo era:

Art. $2^{\circ}$ Seu único e exclusivo objetivo é o progresso da indústria da erva-mate e sua propagação nos mercados europeus e americanos onde ainda não é conhecida afim de abrir novos horizontes a este importante produto da província ${ }^{19}$.

\footnotetext{
${ }^{18}$ Arruda, Gilmar (1986). "Heródoto". In: Ciclo da erva-mate em Mato Grosso do Sul, Campo Grande: Instituto Euvaldo Lodi.

19 Paraná (1888). Relatório do Presidente da Província Joaquim d'Almeida Faria Sobrinho enviado à Assembleia Legislativa em 1888, Curitiba, p. $40 . \quad$ Disponível em <http://www.crl.edu/brazil/provincial/parana> Acesso em junho de 2011. 
Eram membros da associação os fabricantes e exportadores paranaenses, cuja sede estava localizada na cidade de Curitiba, com duas sub-sedes, uma em Antonina e outra em Paranaguá. A preocupação em divulgar as qualidades do mate no mercado externo foi constante ao longo do último quartel do século $\mathrm{XIX}$ até meados do $\mathrm{XX}$. O objetivo era alcançar outros mercados além do argentino, chileno e uruguaio, chegando à Europa e aos Estados Unidos, dois grandes mercados já conhecidos por meio das exportações do café. O café era popularmente conhecimento, de gosto agradável e de fácil aceitação nas redes comerciais nos principais mercados no exterior, não sendo necessário investir na propaganda e difusão do produto. O mesmo não ocorria com a erva-mate, que tinha um gosto amargo e não era conhecida nos bares e restaurantes europeus e norte-americanos. As tentativas dos produtores e exportadores brasileiros eram sempre vãs, e o volume exportado para estes mercados pouco se alterava a cada ano.

\section{Regulação das atividades ervateiras no século $X X$}

A República trouxe algumas normatizações mais amplas para as atividades ervateiras, como a isenção geral de tarifas para a exportação do llex e a proibição de repassar as concessões dos terrenos de ervais. Mas, ao mesmo tempo, dentro do ideal liberal, permitiu a criação de associações regionais com interesses divergentes e não definiu regras uniformes para os procedimentos de colheita, beneficiamento e comercialização do mate.

O Brasil inicia o século XX reafirmando sua posição de economia agrária exportadora mercantil, com a consolidação dos complexos regionais agroexportadores. No Norte, destacavam-se as precárias atividades da extração do látex da seringueira para a produção da borracha; no Nordeste, ainda vigora o secular complexo açucareiro que ensaiava um surto de modernização com a mecanização da produção do açúcar; também no Nordeste, mais precisamente no Maranhão, a produção do algodão ganhava força e ampliava sua participação na pauta de exportação regional; no litoral sul da Bahia, destacavam-se as plantações de cacau; no Rio Grande do Sul, a economia do couro e do charque ainda persistia desde o século XVIII; e no Sudeste, sobretudo em São Paulo, o amplo e integrado complexo cafeeiro, cujo ritmo de acumulação repercutia em várias regiões do País. É dentro da dinâmica econômica e política desses complexos regionais, 
todos voltados "para fora" que temos que entender o desempenho das atividades ervateiras no Paraná, Santa Catarina, Mato Grosso e Rio Grande do Sul.

$\mathrm{Na}$ tabela abaixo, podemos verificar a participação de cada Estado produtor nas exportações de erva-mate. Estes dados revelam o grau de expansão e abrangência do complexo ervateiro em nível estadual. Nas três primeiras décadas do século XX, o Paraná participava com $67,46 \%$ das exportações brasileiras do mate, seguido de Santa Catarina, com 15,58\%, Mato Grosso, com 10,32\%, e Rio Grande do Sul, com 6,64\%. Sem dúvida, o ritmo de acumulação no Paraná era o mais intensivo e extensivo, seguido de Santa Catarina. No planalto norte catarinense e no sudeste do Paraná, envolvendo os vales dos rios Iguaçu e Negro, era onde se concentrava a maioria das atividades ervateiras. No entanto, Curitiba e Joinville eram as duas praças urbanas onde eram mais absorvidos os resultados promovidos pela expansão da renda do complexo ervateiro.

Tabela 1: Participação por Estado nas exportações da erva mate 1901-1930 (em \%)

\begin{tabular}{cccccc}
\hline Ano & Paraná & Santa Catarina & Mato Grosso & Rio Grande do Sul & Total \\
\hline 1901 & 72,68 & 13,40 & 13,40 & 0,52 & 100,00 \\
1910 & 68,12 & 8,68 & 8,56 & 14,65 & 100,00 \\
1920 & 67,37 & 18,02 & 6,74 & 7,88 & 100,00 \\
1930 & 61,67 & 22,23 & 12,56 & 3,53 & 100,00 \\
Média & 67,46 & 15,58 & 10,32 & 6,64 & 100,00 \\
\hline
\end{tabular}

Já na primeira década do século $X X$, as atividades ervateiras ganham a dimensão de um complexo agroexportador, com o desenvolvimento de um amplo sistema de transportes combinando estradas que desciam a Serra do Mar em direção aos portos paranaenses e a moderna Estrada Dona Francisca, entre Joinville e Rio Negro; ferrovias, com a Estrada de Ferro Curitiba-Paranaguá e a Estrada de Ferro São Paulo-Rio Grande e seus ramais no Paraná e em Santa Catarina; navegação fluvial nos rios Iguaçu e Negro; e os portos de Antonina, Paranaguá e São Francisco. Também se consolidavam as unidades de produção, beneficiamento e comercialização da erva-mate, que dinamizavam outras atividades produtivas e comerciais, como oficinas, olarias, marcenarias, ferrarias e, sobretudo, casas comerciais. A presença das atividades ervateiras no planalto norte catarinense e nos vales do Iguaçu e Negro, no Paraná, fixava os colonos imigrantes, impulsionava a renda regional e formava uma rede urbana.

No Gráfico 2, temos o comportamento das exportações entre 1900 e 1935. Destacam-se dois momentos: o de rápida expansão das exportações até 1920, com uma 
leve desaceleração em 1925, e a queda mais acentuada a partir da crise de 1930, com a redução das exportações para a Argentina.

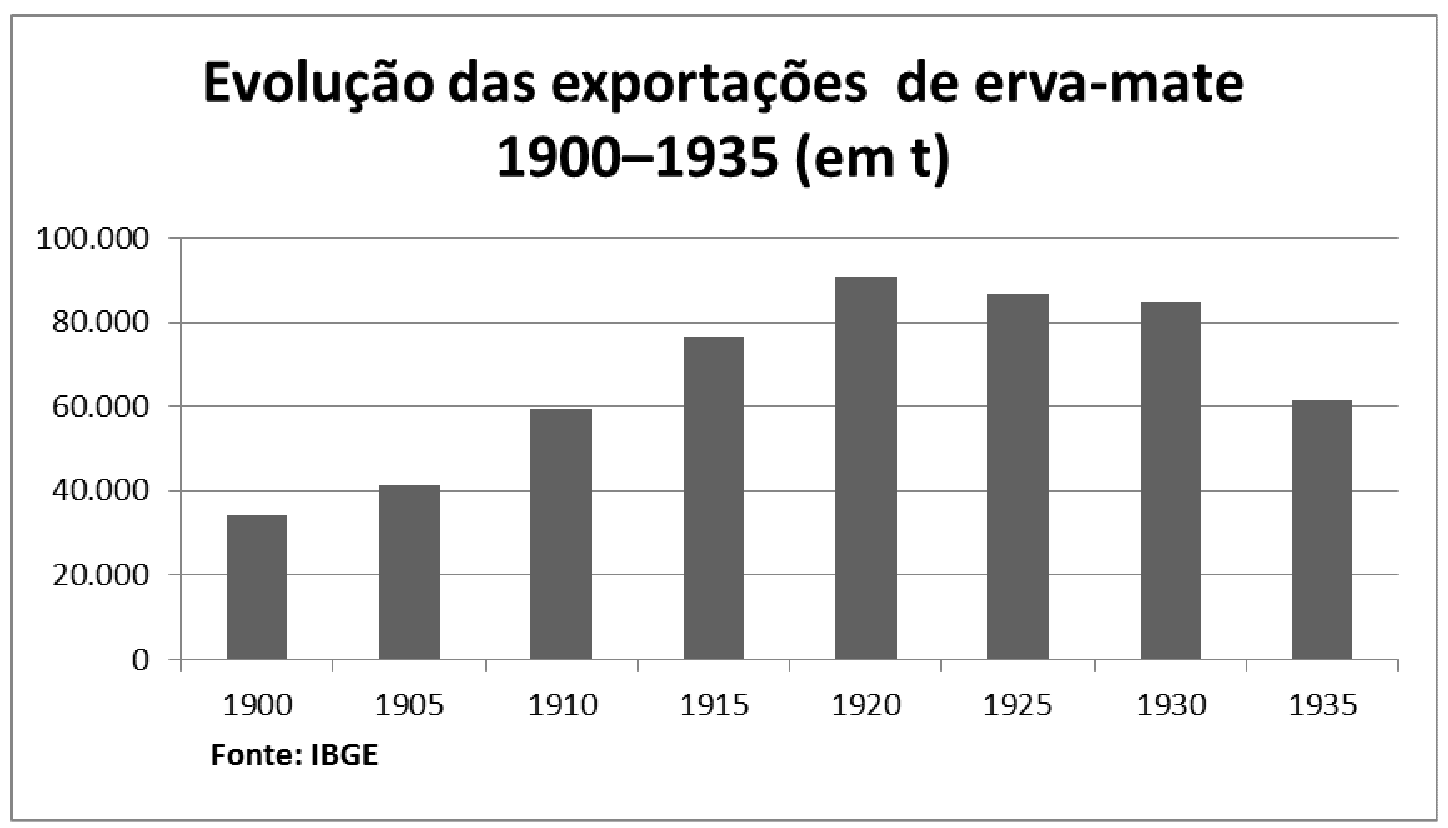

A ampliação das atividades ervateiras formando um complexo agroexportador regional exigia do Estado novos mecanismos de regulação para disciplinar os procedimentos de colheita, produção e comercialização. No Paraná, as leis estaduais que seguiram durante a Primeira República estavam concentradas em duas vertentes: as destinadas à normatização das tarifas de exportação e a tentativa de ajustar um valor em comum com Santa Catarina para evitar perdas para os dois Estados; e as voltadas para o arrendamento das terras devolutas para a colheita do Ilex. Essa "guerra tarifária" foi endossada pelas disputas territoriais entre os dois Estados na grande região do Contestado, onde havia grande reserva de ervais. Após um acordo selado entre os dois Estados, a lei paranaense 1.575, de 22 de março de 1916, e a lei catarinense 933, de 15 de abril de 1916, buscaram definir uma unidade na forma de cobrança tarifária da erva cancheada exportada, sendo cobrada apenas em ouro ${ }^{2021}$.

No que tange à definição da área para colheita, mesmo sob responsabilidade da União, os Estados também legislavam sobre o assunto e definiam a expansão da área agrícola explorável. No Paraná, a Lei 481, de 08 de abril de 1902, autorizou e Executivo a arrendar todos os ervais existentes em terras devolutas por um prazo máximo de até nove

\footnotetext{
${ }^{20}$ Santa Catarina (1916). Coleção de leis, decretos e resoluções do Estado de Santa Catarina de 1916, Florianópolis: Tipografia do O Dia.

${ }^{21}$ Martins, R. (1926). Op. cit.
} 
anos, e cada concessão não poderia exceder a 5.000 hectares, sendo cobrada uma taxa de $1 \$ 000$ a $3 \$ 000$ por hectare, a ser definido pelo governo. Em 1915, foi editada uma nova lei, a 1.540, de 30 de março, que alterou a forma de pagamento para 200 a 500 réis por arroba colhida nos terrenos concedidos. Santa Catarina, com certo atraso, regulamentou a concessão de terras para a colheita do Ilex somente em 1913, com a aprovação da Lei 960, de 14 de agosto. Nela estava previsto que o Executivo estava autorizado a conceder a particulares, gratuitamente, lotes de terras de até 70 hectares para o plantio da erva-mate. O prazo para iniciar as atividades agrícolas era de cinco anos, e estavam proibidas a venda e a permuta da área concedida ${ }^{22}$.

Com a difusão do uso do mate, incorporado no consumo cotidiano por meio do chá quente e gelado, além de infusão (chimarrão), passou-se e exigir que a sua composição química fosse mais selecionada durante o seu processo produtivo. No Paraná, a Lei 2.023, de 12 de março de 1921, determinou a obrigatoriedade da análise química e microscopia da erva exportada e consumida no mercado interno. Pelo que estava previsto na lei, o governo ficaria responsável por criar laboratórios junto aos portos de embarques, em Curitiba e em outros pontos estratégicos. Essa nova lei se juntava a outra já aprovada em 26 de março de 1920 de número 1.956, que criava um "Selo de Garantia Oficial" para o mate que atingisse um padrão de qualidade. Outra novidade legislativa foi a regulamentação da propaganda para divulgá-la no exterior, por meio da Lei 2.107, de 25 de março de 1922, que autorizou o executivo estadual a realizar esta tarefa e abriu um crédito especial para cobrir suas despesas ${ }^{23}$.

Mesmo com os regulamentos de 1854 e 1875, além dos diversos instrumentos legais que disciplinavam a safra da erva-mate, ainda era muito comum a infração praticada tanto pelos produtores como pelos comerciantes. O Estado via-se na condição de constantemente ampliar as normas para minimamente obter ganhos econômicos sem comprometer as safras vindouras. Um novo regulamento foi aprovado no Paraná por meio da Lei 2.015, de 21 de março de 1921, que tratou basicamente de medidas punitivas, por meio de pesadas multas, aos que infringiam o período da colheita.

O primeiro regulamento aprovado em Santa Catarina foi em 1905, por meio da Lei 700 , de 27 de outubro. Nela estava previsto que a colheita poderia ser feita somente entre $1 .^{\circ}$ de maio e 30 de setembro, ficando a mesma árvore três anos em descanso. $\mathrm{O}$ infrator

\footnotetext{
${ }^{22}$ Santa Catarina (1913). Coleção de leis do Estado de Santa Catarina de 1913, Florianópolis: Tipografia do O Dia.

${ }^{23}$ Martins, R. (1926). Op. cit.
} 
seria multado em $10 \$ 000$ a cada 15 quilos colhidos. Também estava proibido o corte da erva muito nova. Essa lei foi assinada por Abdon Baptista, um negociante de erva-mate em Joinville, que assumiu o governo do Estado num curto intervalo entre setembro e novembro de $1906^{24}$. Contudo, os procedimentos para aplicar as multas foram regulamentados somente em 1927 pelo Decreto Estadual 29, de 27 de abril, seguindo a mesma linha que o Paraná já havia adotado em $1921^{25}$. No ano seguinte, foi promulgada a Lei 1.626, de 4 de outubro, que detalhou ainda mais os procedimentos para beneficiamento, embalagem e comercialização, estabelecendo multas e ampliando o grau de fiscalização dos órgãos estaduais sobre a safra da erva-mate ${ }^{26}$.

Novamente, imitando o Paraná, e, tardiamente, o governo catarinense também normatizou, por meio da Lei 1.573, de 1. de setembro de 1927, a propaganda dentro e fora do País, autorizando o Executivo a realizar convênios e destinar auxílio para promover a difusão do consumo do mate ${ }^{27}$. O mesmo ocorreu com a criação de um laboratório junto ao porto de São Francisco, Decreto 1, de 9 de janeiro de 1930, destinado a fazer a análise química do mate exportado com o objetivo de garantir a pureza do produto, o qual seria certificado com um selo de garantia ${ }^{28}$.

No Rio Grande do Sul, um amplo regulamento sobre colheita, preparo, padronização, comércio e fiscalização da erva-mate foi aprovado por meio do Decreto 5.426, de 14 de setembro de 1933, que foi aperfeiçoado pelo Decreto 7.365, de 12 de julho de 1938. Era o mais amplo dos três Estados produtores, e era composto de 56 artigos. O nível de detalhamento era tanto que chegava a definir a gramatura das folhas fragmentadas e moídas. Também estavam definidas as infrações e as formas de penalidades $^{2930}$.

\footnotetext{
${ }^{24}$ Santa Catarina (1906). Coleção de leis do Estado de Santa Catarina de 1905, Florianópolis: Tipografia do O Dia.

${ }^{25}$ Santa Catarina (1927). Regulamento para a colheita da erva mate expedido com o Decreto n. 29 de 27 de abril de 1927, Florianópolis: Imprensa Oficial.

${ }^{26}$ Santa Catarina. Coleção de leis, decretos e resoluções do Estado de Santa Catarina de 1928, Florianópolis: Tipografia da Escola de Artes e Artífices.

${ }_{27}$ Santa Catarina (1928). Mensagem apresentada pelo Governador Adolpho Konder à Assembléia Legislativa, Florianópolis: Imprensa Oficial, $1928 . \quad$ Disponível em <http://www.crl.edu/brazil/provincial/santacatarina> Acesso em junho de 2011.

${ }_{28}$ Santa Catarina (1931). Coleção de leis do Estado de Santa Catarina de 1930, Florianópolis: Livraria Central.

${ }^{29}$ Rio Grande do Sul (1933). Regulamento para o comércio e classificação da erva mate Decreto n. 5.426 de 14 de setembro de 1933, Porto Alegre.

${ }^{30}$ Rio Grande do Su (1938). Regulamento da colheita, preparo, padronização, comércio e fiscalização da erva-mate, Porto Alegre: Imprensa Oficial.
} 
Com o intuito de tentar regular novamente a concessão de terras, a Assembleia Legislativa do Estado do Mato Grosso, aprovou a Lei 725 de 24 de setembro de 1915, que limitou a poder da Companhia Mate Laranjeira em ampliar seus domínios territoriais e reconheceu o direito de posseiros em adquirir terras na área da Companhia em até 3.600 hectares, desde que estivessem morando na localidade antes de $1914^{31}$. Esta lei estadual gerou uma enorme polemica no Estado, pois afrontou diretamente os poderosos interesses da Mate Laranjeira, que imperava na região mopolizando a produção e comercialização da erva mate ${ }^{32}$.

Em 7 de julho de 1924, a Assembleia mato-grossense aprovou a Resolução 991, que autorizava o Poder Executivo a arrendar terras de até um milhão de hectares para a extração do Ilex somente por meio de concorrência pública. A garantia do privilégio nunca poderia ser superior a dez anos. O preço do arrendamento não poderia ser menor que $\$ 200$ por hectare anual ${ }^{33}$.

Durante os anos de 1920 e 1930, além do aumento do número de leis e decretos estaduais regulando as atividades ervateiras, também foram criadas as primeiras instituições que agregavam produtores e comerciantes que defendiam os interesses do setor junto ao mercado e ao governo federal. O aumento do nível de complexidade da economia em geral e das normas jurídicas orientou os capitalistas do setor ervateiro a se protegerem em torno de instituições.

A primeira instituição a ser fundada foi o Instituto do Mate de Santa Catarina, em 20 de dezembro de 1927, cuja sede ficava em Joinville. Seu estatuto foi aprovado por meio do Decreto 2, de 11 de janeiro de 1928. As principais finalidades do Instituto eram as seguintes:

Art. 3 A defesa do mate consistirá em desenvolver e melhorar a sua produção, bem como em aperfeiçoar os processos de sua elaboração, standartizar tipos, preparo e acondicionamento, redução de tarifas ferroviárias e marítimas, impostos, etc. Para tal fim o Instituto auxiliará os governos na execução das leis existentes, podendo sugerir aos mesmos medidas que tendam a proteger o produto.

Art. 40 Instituto somente poderá intervir nos mercados quanto a preços, entrada e saída do produto, no caso de crise aguda e assim mesmo sem ferir interesses contratuais.

Art. 50 Instituto somente intervirá quanto a tipos e marcas de erva-mate no caso de recusa nos mercados consumidores desses mesmos tipos e marcas, com

\footnotetext{
${ }^{31}$ Corrêa Filho, Virgílio (1925). A sombra dos hervaes mattogrossenses, São Paulo: Ed. São Paulo.

32 Jesus, Laércio Cardoso de (2004). Erva-mate: o outro lado - a presença dos produtores independentes no antigo Sul de Mato Grosso 1870-1970. Dissertação (Mestrado em História) - Universidade Federal de Grande Dourados.

${ }^{33}$ Arruda, G. (1986). Op. cit.
} 
alegação fundamentada e a vista do laudo de laboratório de exames que comprove a adulteração do produto ${ }^{34}$.

A criação do Instituto foi bem aceita pelo governo estadual, que manifestou apoio por entender que os produtores não poderiam "deixar de merecer a atenção do

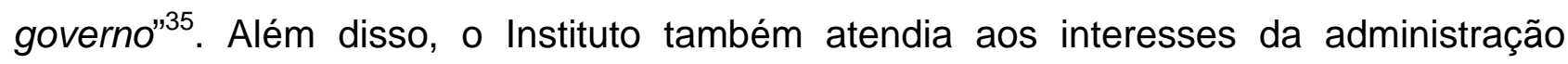
pública, pois protegia e defendia uma das atividades mais expressivas da economia catarinense.

Uma das primeiras atividades do Instituto foi organizar as estatísticas do setor (Mapas Ervateiros do Estado), organizar o Congresso Ervateiro em Florianópolis nos dias 9 e 10 de agosto de 1928, lutar pela redução das tarifas ferroviárias da Estrada de Ferro São Paulo-Rio Grande, divulgar o mate na Europa por meio da participação catarinense na Exposição de Sevilha de $1929^{36}$. Ações desse tipo nortearam a atuação do Instituto durante a sua existência.

Diante da crise de 1929 e da queda acentuada das exportações para a Argentina, que substituía o mate importado pelo nacional, o Instituto reivindicou ao governo estadual que fosse extinto o imposto de exportação como forma de reduzir preço e reconquistar o mercado platino ${ }^{37}$. A pauta pela redução dos impostos e das taxas ferroviárias se arrastou nos anos seguintes. Diante da maior intervenção do Estado na economia brasileira pós1930, a tônica dos discursos do Instituto era de medidas conciliatórias ${ }^{38}$. Na verdade, o agravamento da crise, com queda acentuada nas exportações do mate, acionava o Instituto a buscar soluções imediatas, mas ao mesmo tempo o enfraquecia, pois a sua manutenção dependia do bom desempenho dos produtores e comerciantes.

Em 19 de março de 1931, foi fundado o Sindicato dos Ervateiros de Joinville do Estado de Santa Catarina. Ao contrário do Instituto do Mate, que representava toda a categoria do Estado, o Sindicato estava restrito apenas aos capitalistas localizados em Joinville.

No Paraná, o Instituto do Mate foi criado pela Lei Estadual 2.559, de 2 de abril de 1928, e seu estatuto, aprovado pelo Decreto Estadual 2.141, de 24 de dezembro de 1928. De acordo com seu estatuto, as finalidades do órgão eram as seguintes:

\footnotetext{
${ }^{34}$ Santa Catarina (1928). Op. cit., p. 5.

35 lbidem, p. 92.

36 Instituto do Mate de Santa Catarina (1929). Relatório da diretoria apresentado à Assembleia Geral Ordinária de 15 de janeiro de 1929, Joinville.

${ }^{37}$ Instituto do Mate de Santa Catarina (1933). Memorial, Joinville.

${ }^{38}$ Instituto do Mate de Santa Catarina (1934). Oficio ao Interventor Federal de Santa Catarina, Joinville.
} 
a) defesa e propaganda da erva-mate dentro e fora do País;

b) celebração de convênios com os demais Estados produtores de erva-mate;

c) auxílio ao governo na execução e fiscalização das leis e regulamentos em vigor, referentes à erva-mate;

d) colaboração com o governo, por sugestões oportunas, para acautelar os interesses da indústria de beneficiar ou canchear ${ }^{39}$.

Uma das primeiras iniciativas adotadas foi a criação da Casa do Mate, um espaço público para difundir o uso do chá com sedes em Rio de Janeiro, São Paulo e Fortaleza ${ }^{40}$. A atuação do instituto paranaense não se diferenciou muito do catarinense, que logo se viu embrenhado na crise pós-1929 e tentou formular medidas paliativas para acalmar seus sócios, reivindicando junto ao governo políticas fiscais menos taxativas.

No Rio Grande do Sul, o Instituto do Mate foi criado pelo Decreto Estadual 4.857, de 14 de setembro de 1931. O Estado gaúcho participava com 6,64\% da produção nacional e concentrada em pequenos agricultores e em poucos engenhos de beneficiamento. Contudo, era o maior consumidor nacional, destacando uma rede de casas comerciais que revendia o mate em todo o território estadual. Portanto, era de grande interesse da economia sul-rio-grandense que as atividades ervateiras em Santa Catarina, no Paraná e no Mato Grosso tivessem um bom desempenho. Entre as finalidades expressas no estatuto gaúcho, estavam:

\footnotetext{
1. cooperar com o Conselho Nacional do Mate e os outros institutos para a abertura de novos mercados de consumo;

2. - melhorar os produtos da indústria e combater a fraude;

3. conhecer pela análise a composição das ervas produzidas nas diferentes zonas do Estado;

4. ${ }^{\circ}$ fazer propaganda intensa para o consumo ${ }^{41}$.
}

Em 1933, foi criado o Sindicato dos Ervateiros do Rio Grande do Sul, que atuava junto com o instituto gaúcho na defesa dos seus interesses econômicos.

A criação dos institutos e dos sindicatos ocorreu num momento em que as atividades do complexo ervateiro ainda estavam em franca expansão no Brasil. Porém, a

\footnotetext{
${ }^{39}$ Paraná (1929). Mensagem do Governador do Estado Affonso Alves Camargo enviada ao Congresso Legislativo, Curitiba, p. 46. Disponível em <http://www.crl.edu/brazil/provincial/parana> Acesso em junho de 2011.

40 Paraná (1930). Mensagem do Governador do Estado Affonso Alves Camargo enviada ao Congresso Legislativo, Curitiba. Disponível em <http://www.crl.edu/brazil/provincial/parana> Acesso em junho de 2011.

${ }^{41}$ Federação das Associações Rurais do Estado do Rio Grande do Sul (1932). Anais do VI Congresso Rural efetuado em Porto Alegre de 10 a 13 de julho de 1932, Porto Alegre: Tipografia Gundlach.
} 
atuação mais efetiva de ambos ocorrerá na primeira metade dos anos de 1930, quando eclodiu a crise mundial, repercutindo diretamente nas exportações da llex para o mercado platino. As tentativas isoladas dos institutos em buscar solução para a crise crônica eram malsucedidas, pois, a partir de 1930, o direcionamento para a economia brasileira foi outra. Como sabemos, o liberalismo federativo que imperou na Primeira República é substituído pela centralização das tomadas de decisão nas mãos do Executivo federal, sob a batuta de Getúlio Vargas, que passou a comandar um projeto de desenvolvimento nacional, sobrepondo os interesses regionais. Nesse sentido, os institutos estaduais do mate estavam na contramão dos objetivos nacionais.

\section{A atuação do Instituto Nacional do Mate}

O Estado que surgiu após a Revolução de 1930, além de ampliar a sua base de atuação, passou a centralizar, burocratizar e racionalizar ainda mais as suas funções. Do ponto de vista econômico, os anos de 1930 inauguram também um novo padrão de acumulação, o da industrialização restringida. $O$ velho padrão agrário mercantil exportador foi suplantado pela industrialização, e os complexos regionais, pelo projeto nacional de economia. Diante das exigências impostas pelo novo padrão de acumulação, o Estado viu-se obrigado a assumir várias funções onde havia uma inércia empresarial, falta de comando e de capital.

A crise dos complexos regionais foi encampada pelo Estado, que se viu na obrigação de atender aos reclames das oligarquias locais, nacionalizando os problemas das atividades agrícolas exportadoras. Vargas buscou acomodar interesses regionais tendo como norte um projeto nacional de industrialização. Nessa esteira foram criados, em 1931, o Conselho Nacional do Café, o Conselho Nacional do Mate e o Instituto do Cacau da Bahia. Em 1933, foram criados o Instituto do Álcool e do Açúcar e o Departamento Nacional do Café, que assumiram as funções dos antigos Conselhos. Em boa medida, esses órgãos federais buscavam proteção no Executivo federal para defender a agricultura da queda dos preços e nas exportações. Eles também passaram a normatizar com mais vigor a safra e os procedimentos de beneficiamento e comercialização do produto acabado. Na verdade, era uma ampliação da participação do Estado nas atividades agrícolas com permissão dos capitalistas que viam nessa ação a 
única forma de sobrevivência de seus negócios. Como é sabido, essa foi a atuação do governo Vargas que se estendeu para várias áreas da economia e da sociedade.

A criação do Conselho Nacional do Mate, em 1931, foi a primeira tentativa de nacionalizar os problemas do complexo ervateiro. O Conselho atuava com os institutos regionais do mate na tentativa constante de garantir preço e ampliar mercado para o setor, pois, diante da queda acentuada das exportações, sobretudo para a Argentina, a sobrevivência de muitos produtores e comerciantes estava ameaçada. Mesmo com a presença do Conselho, que buscava uma solução nacional, os interesses regionais defendidos pelos institutos dificultavam a busca de uma solução uniforme para o complexo, que começa a agonizar.

A tentativa de buscar uma solução nacional para o problema do mate veio com a criação do Instituo Nacional do Mate (INM) por meio do Decreto-Lei 375, de 13 de abril de 1938. Formado por uma junta deliberativa, uma diretoria e um presidente, o INM tinha os seguintes objetivos:

1) promover, junto aos governos federal e estaduais, a unificação das leis e regulamentos que, relativos ao mate, disponham desde a colheita até à sua entrega ao consumo, tendo em conta as condições naturais de cada região, os métodos de análise, a classificação dos tipos de exportação e proibir a exportação de ervas inferiores;

2) sugerir aos governos da União e dos Estados todas as medidas que deles dependerem e forem julgadas necessárias para melhorar os processos de cultura do mate, bem como do seu beneficiamento e transporte;

3) assentar as bases das instruções que devem ser ministradas aos produtores, comerciantes e exportadores, com o fim de melhorar o produto e prepará-lo segundo as exigências dos mercados consumidores;

4) fixar, anualmente, a taxa de propaganda prevista neste decreto-lei;

5) prestar auxílio financeiro à produção e à indústria, visando ao seu aperfeiçoamento;

6) estudar e estabelecer as bases para a propaganda do mate, no país e no exterior, devendo ser confiada, de preferência, a agências especializadas;

7) promover entendimentos com organizações congêneres de outros países produtores para uma ação conjunta relativamente à propaganda do mate ${ }^{42}$.

Com relação à atuação dos institutos regionais, ficou designado que os mesmos passariam a ser os representantes do INM nos Estados, os quais deveriam moldar sua organização e regulamento nos moldes do estatuto do INM.

\footnotetext{
42 Instituto Nacional do Mate (1939). Relatório apresentado a Diretoria do Instituto Nacional do Mate, Rio de Janeiro: INM, p.10.
} 
Em seguida, o Decreto 3.128, de 5 de outubro de 1938, aprovou o regulamento do INM, que detalhou as atribuições da junta deliberativa, da diretoria e do presidente, além de ordenar a atuação do Instituto nas suas divisões, seções e agências. Foi normatizada a atuação do INM no exterior por intermédio de agências que ficavam encarregadas de difundir o uso do mate por meio de propaganda. Aliás, a seção de propaganda era uma da mais debatidas no INM, pois se achava que bastava melhorar a apresentação do mate brasileiro no exterior para que sua demanda crescesse.

O INM começou a operar com 89 trabalhadores, duas sedes representativas (Curitiba e Joinville), uma sede administrativa que ficava no Rio de Janeiro e representantes dos quatro Estados produtores. Inicialmente, foram 81 fabricantes inscritos, sendo 19 do Paraná, seis de Santa Catarina e 46 do Rio Grande do Sul, e 33 comerciantes, 14 do Paraná, oito de Santa Catarina, três do Rio Grande do Sul, seis do Mato Grosso e dois de São Paulo. Ao longo da existência do INM, o número de inscritos foi crescendo lentamente, sem grandes sobressaltos.

Um novo regulamento, mais amplo e detalhado, foi aprovado por meio do Decreto 7.902, de 24 de setembro de 1941, já como resultado da atuação do INM. No decreto estavam estabelecidas as especificações e tabelas para classificação e fiscalização da exportação da erva-mate com objetivo de padronizar seus procedimentos.

Uma das primeiras grandes iniciativas do Instituto foi estimular e amparar a criação de cooperativas de produtores da erva-mate como forma de protegê-los das constantes mudanças no preço e queda das exportações. Esse movimento vinha desde 1935, quando foi criada, entre os institutos paranaense e catarinense, a Confederação Interestadual dos Consórcios Profissionais Cooperativos. Em 1945, quando da realização do Primeiro Congresso Cooperativo dos Ervateiros do Brasil, havia registrados quase 3.000 produtores da erva nativa, agregados em 19 cooperativas, 15 do Paraná e quatro de Santa Catarina. Basicamente, em cada município produtor, havia uma cooperativa, como exemplo, em Santa Catarina, havia em Canoinhas, Campo Alegre, Mafra e Porto União ${ }^{43}$.

No Relatório do INM de 1945, temos uma base das ações empreendidas pela instituição em defesa dos produtores nacionais:

\footnotetext{
${ }^{43}$ Anais do Congresso Cooperativo dos Ervateiros do Brasil (1945). Congresso Cooperativo dos Ervateiros do Brasil, Rio de Janeiro.
} 
Instalado o Instituto a sua ação começou pela única forma possível: a defesa da economia nacional que se empobrecia na exportação do produto a baixo preço, determinado pelo excedente de safras anteriores, no mercado produtor ${ }^{44}$.

Foram fixados preços e coibida a importação, assim a produção e os "ganhos" dos produtores poderiam ser normalizados. Porém, esse problema sempre era reposto a cada safra, cuja oferta sempre superava as expectativas da demanda externa. Nas décadas de 1940, 1950 e 1960, a trajetória das exportações da erva-mate foi muito instável, ora apresentando um crescimento razoável, para em seguida iniciar uma queda mais acentuada (Gráfico 3). No mercado interno, o consumo com base no chá de mate passou a ser mais difundido somente a partir do final dos anos de 1950: "a indústria do 'mate solúvel' continua com as melhores e mais amplas perspectivas de êxito, principalmente nos novos mercados ${ }^{\prime \prime 4}$. Portanto, essa instabilidade na demanda externa e interna era um dos pontos mais destacados na série dos Relatórios do INM de 1939 a 1966.

Outra iniciativa do INM foi atuar com o Banco do Brasil, que também passou a financiar a safra da erva. Essa iniciativa aliviou temporariamente a situação dos produtores, que sempre recorriam ao aumento dos preços para repor perdas imediatas.

Para promover o mate no exterior, foi aberta uma agência de propaganda em Nova York, onde o INM manteve um escritório que se encarregava de contatar empresas interessadas no mate brasileiro ${ }^{46}$. O Instituto apostava muito nessa agência, pois se acreditava que a propaganda seria a melhor forma de ampliar o mercado do mate no exterior. Ledo engano, pois a maior barreira estava no gosto amargo do mate, que não conquistava o paladar europeu e norte-americano, já acostumados com o café brasileiro.

Outra forma de atuar em colaboração com os produtores foi por meio da instalação e da manutenção de unidade de beneficiamento e laboratórios de uso coletivo. Foram construídos dois barbaquás coletivos, um em Canoinhas, outro em Prudentópolis, além de três campos de semente localizados em Mafra, Lapa, Prudentópolis, e três campos de multiplicação de mudas em Lapa, São Mateus e Mafra. O barbaquá coletivo de Canoinhas não alcançou seus objetivos e, aos poucos, foi sendo abandonado ${ }^{4748}$.

\footnotetext{
${ }^{44}$ Instituto Nacional do Mate (1945). Relatório do Presidente à Junta Deliberativa, Rio de Janeiro: INM, p. 3-4.

${ }^{45}$ Instituto Nacional do Mate (1959). Relatório apresentado pelo Presidente Pedro Firman Neto à Junta Deliberativa, Rio de Janeiro: INM, p. 3.

${ }^{46}$ Instituto Nacional do Mate (1947). Relatório apresentado pelo Presidente Generoso Ponce Filho à Junta Deliberativa, Rio de Janeiro: INM.

${ }_{47}$ Instituto Nacional do Mate (1958). Relatório apresentado pelo Presidente Antônio Souza Artigas à Junta Deliberativa, Rio de Janeiro: INM.
} 
Contudo, para poder atender às demandas do setor ervateiro, o INM necessitava manter toda estrutura administrativa no Rio de Janeiro e ampliar sua atuação nos Estados produtores, sobretudo com fiscais que monitoravam a qualidade do produto exportado. No Relatório de 1953, o presidente reclamava que a "receita limitada e encargos dispendiosos" dificultavam a ação do INM: "é o maior obstáculo para que a autarquia atinja, de maneira completa e segura, as suas altas finalidades" ${ }^{\prime 4}$. O excesso de pessoal era apontado como um dos fatores que absorviam muito dos parcos recursos disponíveis, cuja solução apontada seria a transferência para outra autarquia. Na verdade, a baixa arrecadação tinha mais a ver com a instabilidade do setor, que enfrentava periodicamente crises. No gráfico abaixo, podemos acompanhar esta instabilidade com tendência de queda das exportações. Após a criação do INM, o setor seguiu uma trajetória descendente até 1952, quando inicia uma lenta recuperação para, em seguida, cair novamente. O volume exportado em 1966, de 35.421 t de Ilex, foi próximo da quantidade do ano de 1900, quando foram exportados 33.992 t. Estávamos assistindo no setor ervateiro a uma regressão lenta e contínua.

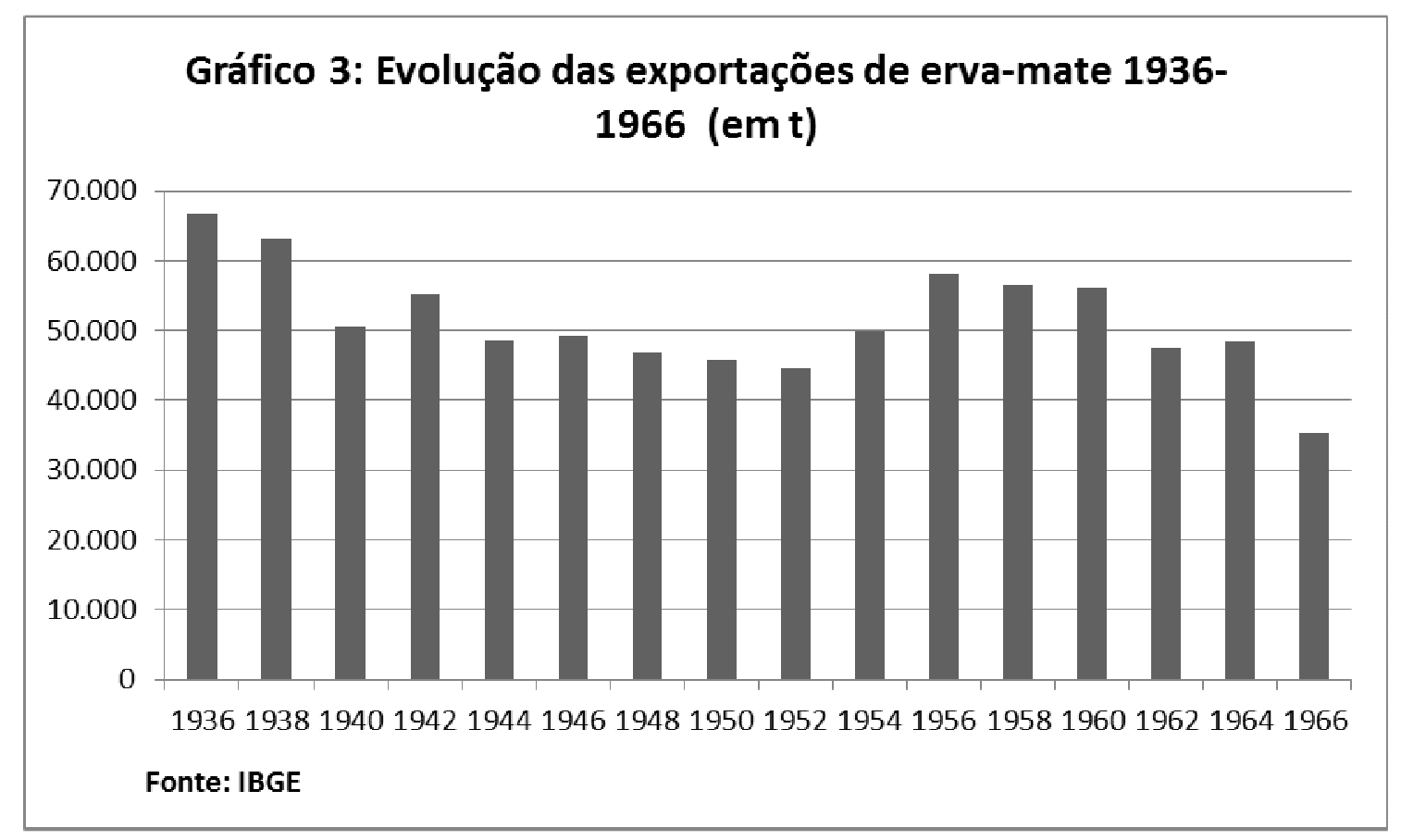

\footnotetext{
48 Instituto Nacional do Mate (1962). Relatório apresentado pelo Presidente Cândido Mader à Junta Deliberativa, Rio de Janeiro: INM.

${ }^{49}$ Instituto Nacional do Mate (1953). Relatório apresentado à Junta Deliberativa, Rio de Janeiro: INM, p. 1.
} 
Para combater o secular problema da erva alterada, o Instituto desencadeou uma campanha para substituir os engenhos antigos por modernos que atendiam às normas sanitárias:

Prossegue o Instituto, sem tréguas, na sua campanha de substituir os engenhos antiquados e condenados por outros que se enquadrem num mínimo de condições técnicas e higiênicas. O trabalho, que é um combate frontal à rotina, tem sido árduo, mas está sendo vitorioso ${ }^{50}$.

Em toda a região ervateira do País, ainda resistia o antigo sistema de produção. Diante do "discurso do progresso" e da necessidade de conquistar mercados mais exigentes com o mate solúvel, foram se implantando métodos e técnicas avançadas que melhor aproveitavam a erva, mas que ao mesmo tempo aceleravam o processo de degradação ambiental.

Em verdade, os nossos grandes engenhos estão desaparelhados para satisfazer convenientemente a um beneficiamento em larga escala, bem como atender os requisitos de padronização e baixo custo do produto, indispensável ao fomento do consumo ${ }^{51}$.

Como ainda havia pequenos e inúmeros soques espalhados nas áreas ervateiras, na avaliação do INM, não seria possível oferecer segurança aos que nele trabalhavam, além de o produto final apresentar impurezas. Para agravar o problema, havia os engenhos "clandestinos", que atuavam longe da fiscalização do Instituto ${ }^{52}$.

A ditadura militar no Brasil inaugurou um "novo" regime administrativo na esfera pública mais pautada na tecnocracia. Alguns órgãos foram extintos e outros, potencializados. A racionalização dos processos administrativos levava em consideração as acomodações dos interesses do patrimonialismo e do estamento, ao mesmo tempo em que buscava eficiência financeira. Nesse movimento que combinava o moderno com o arcaico foi encaminhada a extinção do INM.

Durante o governo do General Humberto Castelo Branco, por meio do Decreto-Lei 281, de 28 de fevereiro de 1967, foi extinto o INM, que atuou durante quase 39 anos defendendo os interesses dos capitalistas da erva-mate. As atribuições do INM foram

\footnotetext{
${ }^{50}$ Instituto Nacional do Mate (1957). Relatório apresentado pelo Presidente Antônio Souza Artigas à Junta Deliberativa, Rio de Janeiro: INM, p.3.

${ }_{51}$ Instituto Nacional do Mate (1964). Relatório apresentado pelo Presidente Jorge de Lima à Junta Deliberativa, Rio de Janeiro: INM, p. 7.

52 Instituto Nacional do Mate (1965). Relatório apresentado pelo Presidente Manuel de Oliveira Franco Sobrinho à Junta Deliberativa, Rio de Janeiro: INM.
} 
transferidas para o recém-criado Instituto Brasileiro de Desenvolvimento Florestal (IBDF), por meio do Decreto 61.680, de 13 de novembro de 1967. Dentro do IBDF, foi criado o Departamento da Erva-Mate, cujas funções eram executar a política de produção, beneficiamento, comercialização e propaganda da ervamate. Contudo, com um poder de intervenção menor que o extinto INM. O IBDF era mais voltado para a defesa e fiscalização, ao contrário do INM, que estava focado no fomento. Estavam sendo gestados novos conflitos de interesses no setor ervateiro.

\section{Considerações finais}

A trajetória de intervenção do Estado, a ampliação dos mecanismos regulatórios e a criação de instituições promotoras e protetoras das atividades ervateiras cresceram paulatinamente com a formação e expansão do complexo ervateiro no Brasil, centrado nos Estados do Paraná, Santa Catarina, Mato Grosso e Rio Grande do Sul. A mudança nas bases concretas do complexo ervateiro e a ampliação do mercado exigiam um maior disciplinamento no processo de colheita, beneficiamento e comercialização da Ilex.

No século XIX, bastava definir algumas regras básicas do processo produtivo para evitar a contaminação da erva com outros vegetais. Temos como exemplo o regulamento aprovado em 1855 pelo governo do Paraná e que tinha apenas oito artigos. Com a ampliação do número de produtores e a conquista do mercado platino, que era mais exigente, o Estado viu-se na obrigação de controlar a qualidade do mate exportado, para, inclusive, garantir seus ganhos fiscais promovidos pelo aumento das exportações. Com isso, foi aumentando o cerco contra os produtores que não seguiam um mínimo de qualidade.

Para organizar o processo de concessão dos ervais no Mato Grosso, o governo Imperial começou a expedir privilégios para capitalistas brasileiros que almejavam fazer a colheita nas terras devolutas. $\mathrm{Na}$ prática, muitas dessas áreas concedidas eram extrapoladas além das definidas em leis, mas revela uma ação do Estado no sentido de disciplinar o acesso aos ervais.

Durante a Primeira República, sob o auspício do federalismo liberal, num mosaico de complexos regionais agroexportadores, a regulação ficava mais a cargo dos governos locais. Diante do processo de aceleração da produção, ampliação do mercado e, sobretudo, em função das constantes instabilidades, os produtores e comerciantes da 
erva-mate buscaram se resguardar em instituições promotoras e protetoras dos seus interesses com a criação de institutos e sindicatos.

Os anos de 1930 inauguram nova etapa na economia brasileira pondo em marcha um acelerado processo de industrialização e centralização das ações estatais. Vargas nacionalizou os problemas regionais para evitar a fragmentação da economia. Foi nesse movimento que, em 1938, criou-se o Instituto Nacional do Mate. O INM atuou durante quase 39 anos fomentando a produção, disciplinando o processo produtivo e comercial e protegendo os capitalistas do setor ervateiro da queda dos preços. A extinção do INM, em 1966, retirou da pauta de prioridades do governo federal a erva-mate, que passou a ser subordinada ao recém-criado IBDF, que fiscalizava o corte dos ervais.

\section{Referências Bibliográficas}

Alencar, F. Rodrigues (1960). Erva-mate, Rio de Janeiro: Serviço de Informação Agrícola.

Arruda, Gilmar (1986). "Heródoto". In: Ciclo da erva-mate em Mato Grosso do Sul, Campo Grande: Instituto Euvaldo Lodi.

Brasil (1837). Relatório da Repartição dos Negócios do Império apresentado pelo Ministro Antonio Paulino Limpo de Abreu à Assembleia Geral Legislativa em 1837. Rio de Janeiro: Tipografia Nacional. Disponível em < http://www.crl.edu/brazil/ministerial/imperio> Acesso em junho de 2011.

Brasil (1882). Coleção de Leis do Império do Brasil de 1882. Rio de Janeiro: Imprensa Nacional. Disponível em < http://www.camara.gov.br/Internet/InfDoc/Conteudo/Colecoes/Legislacao > Acesso em junho de 2011.

Cano, Wilson (1990). Raízes da concentração industrial em São Paulo, São Paulo: Hucitec.

Corrêa Filho, Virgílio (1925). A sombra dos hervaes mattogrossenses, São Paulo: Ed. São Paulo.

Costa, Francisco Leite Alves (1935). O mate: exploração, indústria e exportação, Rio de Janeiro: Diretoria de Estatística da Produção.

Federação das Associações Rurais do Estado do Rio Grande do Sul (1932). Anais do VI Congresso Rural efetuado em Porto Alegre de 10 a 13 de julho de 1932, Porto Alegre: Tipografia Gundlach.

Instituto Brasileiro de Geografia e Estatística (vários anos). Anuários Estatísticos do Brasil, Rio de Janeiro: Ministério do Planejamento. 
Instituto do Mate de Santa Catarina (1929). Relatório da diretoria apresentado à Assembleia Geral Ordinária de 15 de janeiro de 1929, Joinville.

(1933). Memorial, Joinville.

(1934). Oficio ao Interventor Federal de Santa Catarina, Joinville.

Instituto Nacional do Mate (1939). Relatório apresentado a Diretoria do Instituto Nacional do Mate, Rio de Janeiro: INM.

(1945). Relatório do Presidente à Junta Deliberativa. Rio de Janeiro: INM.

(1947). Relatório apresentado pelo Presidente Generoso Ponce Filho à Junta Deliberativa, Rio de Janeiro: INM.

(1953). Relatório apresentado à Junta Deliberativa, Rio de Janeiro: INM.

(1957). Relatório apresentado pelo Presidente Antônio Souza Artigas à Junta Deliberativa, Rio de Janeiro: INM.

(1958). Relatório apresentado pelo Presidente Antônio Souza Artigas à Junta Deliberativa, Rio de Janeiro: INM.

(1959). Relatório apresentado pelo Presidente Pedro Firman Neto à Junta Deliberativa, Rio de Janeiro: INM.

(1962). Relatório apresentado pelo Presidente Cândido Mader à Junta Deliberativa, Rio de Janeiro: INM.

(1964). Relatório apresentado pelo Presidente Jorge de Lima à Junta Deliberativa, Rio de Janeiro: INM.

(1965). Relatório apresentado pelo Presidente Manuel de Oliveira Franco Sobrinho à Junta Deliberativa, Rio de Janeiro: INM.

Jesus, Laércio Cardoso de (2004). Erva-mate: o outro lado - a presença dos produtores independentes no antigo Sul de Mato Grosso 1870-1970. Dissertação (Mestrado em História) - Universidade Federal de Grande Dourados.

Linhares, Temístocles (1969). História econômica do mate, Rio de Janeiro: Livraria José Olympio.

Martins, Romário (1926). Ilex-mate, chá sul americano, Curitiba: David Carneiro Paraná (1854). Relatório do Presidente da Província Zacarias de Góes e Vasconcellos enviado à Assembleia Legislativa em 1854. Curitiba: Tipografia Paranaense de Cândido Martins Lopes. Disponível em <http://www.crl.edu/brazil/provincial/parana> Acesso em junho de 2011. 
(1855). Relatório do Presidente da Província Zacarias de Góes e Vasconcellos enviado à Assembleia Legislativa em 1855, Curitiba. Disponível em <http://www.crl.edu/brazil/provincial/parana> Acesso em junho de 2011.

(1865). Relatório do Ministério da Agricultura, Comércio e Obras Públicas apresentado pelo Ministro Jesuino Marcondes de Oliveira Sá à Assembleia Geral Legislativa em 1865, Rio de Janeiro: Tipografia Universal Laemmert. Disponível em <ttp://www.crl.edu/brazil/ministerial/imperio> Acesso em junho de 2011.

(1879). Relatório do Presidente da Província Manuel Pinto de Souza Dantas Filho

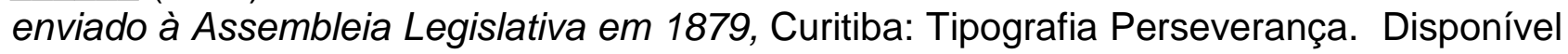
em <http://www.crl.edu/brazi//provincial/parana> Acesso em junho de 2011.

(1888). Relatório do Presidente da Província Joaquim d'Almeida Faria Sobrinho enviado à Assembleia Legislativa em 1888, Curitiba. Disponível em <http://www.crl.edu/brazil/provincial/parana> Acesso em junho de 2011.

(1929). Mensagem do Governador do Estado Affonso Alves Camargo enviada ao Congresso Legislativo. Curitiba. Disponível em <http://www.crl.edu/brazil/provincial/parana> Acesso em junho de 2011.

(1930). Mensagem do Governador do Estado Affonso Alves Camargo enviada ao Congresso Legislativo. Curitiba. Disponível em <http://www.crl.edu/brazil/provincial/parana> Acesso em junho de 2011.

Rio Grande do Sul (1933). Regulamento para o comércio e classificação da erva mate Decreto n. 5.426 de 14 de setembro de 1933, Porto Alegre.

(1938). Regulamento da colheita, preparo, padronização, comércio e fiscalização da erva-mate, Porto Alegre: Imprensa Oficial.

Santa Catarina (1874). Coleção das Leis da Província de Santa Catarina de 1874, Desterro: Tipografia J. J. Lopes.

(1887). Leis e resoluções da Província de Santa Catarina de 1887, Desterro: Tipografia do Conservador.

(1906). Coleção de leis do Estado de Santa Catarina de 1905, Florianópolis: Tipografia do O Dia.

(1916). Coleção de leis, decretos e resoluções do Estado de Santa Catarina de 1916, Florianópolis: Tipografia do O Dia.

(1913). Coleção de leis do Estado de Santa Catarina de 1913, Florianópolis: Tipografia do O Dia.

(1927). Regulamento para a colheita da erva mate expedido com o Decreto $n .29$ $\overline{\text { de } 27}$ de abril de 1927, Florianópolis: Imprensa Oficial. 
(1928). Coleção de leis, decretos e resoluções do Estado de Santa Catarina de 1928, Florianópolis: Tipografia da Escola de Artes e Artífices.

(1928). Mensagem apresentada pelo Governador Adolpho Konder à Assembléia Legislativa, Florianópolis: Imprensa Oficial, $1928 . \quad$ Disponível em <http://www.crl.edu/brazil/provincial/santacatarina> Acesso em junho de 2011.

(1931). Coleção de leis do Estado de Santa Catarina de 1930, Florianópolis: Livraria Central.

Silva, Victor Ferreira do Amaral e Silva (1900). Erva-mate: sua cultura, colheita e preparo, Rio de Janeiro: Sociedade Nacional de Agricultura.

Recebido para publicação em 26 de novembro de 2012.

Aprovado para publicação em 29 de janeiro de 2013. 